\title{
Effect of fertilizer application and the main nutrient limiting factors for yield and quality of sugarcane production in Guangxi red soil
}

\author{
Hongwei Tan, Liuqiang ZHou, Rulin XIE and Meifu HuAnG \\ Institute of Soil and Fertilizer, Guangxi Academy of Agricultural Sciences, 44 Da Xue Road, Nanning 530007, P. R.China \\ E-mail: hwtan@public.nn.gx.cn
}

\begin{abstract}
The two tested soils were poor in nitrogen, phosphorous, potassium, magnesium and sulphur. Application of potassium, magnesium and sulphur, increased the sugarcane yield significantly. Treatments with potassium, magnesium and sulphur fertilizer increased sucrose content markedly. Increased use of potassium, magnesium and sulphur fertilizer increased sugarcane's fiber content.

The biomass production is $80-140$ tons per hectare. Sugarcane growth is divided into four stages: seedling, tiller, stretching, and mature. Sugarcane grows quickly during tillering and stretching periods, also during these stages sugarcane biomass production is greater and more minerals are absorbed, especially potassium, than at other stages. In every development stage of sugarcane, the potassium content of a sugarcane plant is higher than other nutrient elements, except for nitrogen. Generally, sugarcane yield is $45000-$ $60000 \mathrm{~kg}$ per hectare. The absorbable potassium $\left(\mathrm{K}_{2} \mathrm{O}\right)$ amount of sugarcane was 109.1-315.28 $\mathrm{kg}$ per hectare.

According to the statistical results of 82 field experiments in Nanning and Laibin, sugarcane yield and the amount of potassium sugarcane absorbed was significantly and positively correlated. The correlation coefficient was $r=0.979^{* *}$. The function of the sugarcane yield (y) with the amount of potassium sugarcane absorbs (x) was $\mathrm{y}=31687.1+246.0 \mathrm{x}$.
\end{abstract}

Key words: nutrient limitation factors, yield, quality, sugarcane production

\section{INTRODUCTION}

Guangxi is located in the southern area of sub-tropical China, and has land suitable to grow various sub-tropical crops, especially sugarcane. In the past few years, sugarcane production had been developed greatly. In 2003, the total area of sugarcane production had reached 540,000 hectares. Due to poor inputs and extensive cultivation and management, the yield of sugarcane was only 45 to 60 tons/ha, and quality was low. According to our investigation, the highest sugarcane yields in Guangxi were 90 to 150 ton/ha (Guangxi statistical handbook). In order to increase Guangxi sugarcane yield and quality, the effect of fertilizer application and the main nutrient limiting factors for yield and quality were studied.

For sugarcane that usually grows on medium light soils (loam soils), the critical soil $\mathrm{K}$ value was $52.0 \mathrm{mg} \mathrm{kg}^{-1}$ of available $\mathrm{K}$. The critical soil $\mathrm{K}$ value of sandy soil and clay soil are $46.0 \mathrm{mg} \mathrm{kg}^{-1}$ and $60.0 \mathrm{mg} \mathrm{kg}^{-1}$ of available K, respectively. Based on statistical analyses, $\mathrm{K}$ supply classes were established for loam soil: $<52.0 \mathrm{mg} \mathrm{kg}^{-1}, 52.0-110 \mathrm{mg}$ $\mathrm{kg}^{-1}$ and $>110 \mathrm{mg} \mathrm{kg}^{-1}$, corresponding to low, medium and high $\mathrm{K}$ supply, respectively.

Potassium application increased sugarcane yield significantly. When the potassium application rate was between 150-450 kg/ha, sugarcane yield increased $4.75-23.78 \%$. Application of phosphorus fertilizer also increased the yield of sugarcane. Application of $\mathrm{K}$ fertilizer also increased the quality of sugarcane markedly.

\section{MATERIALS AND METHODS}

\section{Soil background}

Trial sites were located in the sugarcane planting region of Guangxi, and two field trials were conducted, one in a suburb of Nanning, another in Laibin county. The selected soils at Nanning and Laibin were classified as siliceous silty soil and red soil, respectively. Both of these soils are derived from Quaternary red earth.

\section{Experimental design and rates of fertilizer application}

a) Group 1:

Six treatments were designed in this experiment. The fertilizer application rates of each treatment are presented in Table 1.

b) Group 2:

Field experiments were conducted from1991 to 2002. Treatments of NP, $\mathrm{NPK}_{1}, \mathrm{NPK}_{2}, \mathrm{NPK}_{3}$ were applied in the field trials. The fertilization rate was $375 \mathrm{~kg} / \mathrm{ha}$ for $\mathrm{N}, 120 \mathrm{~kg} / \mathrm{ha}$ for $\mathrm{P}_{2} \mathrm{O}_{5}$ and $150-450 \mathrm{~kg} / \mathrm{ha}$ for $\mathrm{K}_{2} \mathrm{O}$. 
Table 1. Fertilizer application rates of various treatments $(\mathrm{kg} / \mathrm{ha})$

\begin{tabular}{|l|l|l|l|l|}
\hline Treatments & $\mathrm{N}$ & $\mathrm{P}_{2} \mathrm{O}_{5}$ & $\mathrm{~K}_{2} \mathrm{O}$ & $\mathrm{N}: \mathrm{P}_{2} \mathrm{O}_{5}: \mathrm{K}_{2} \mathrm{O}$ \\
\hline $\mathrm{NPK}_{0}$ & 375 & 120 & 0 & $1: 0.32: 0$ \\
\hline $\mathrm{NPK}_{1}$ & 375 & 120 & 330 & $1: 0.32: 0.88$ \\
\hline NPKMg & 375 & 120 & 330 & $1: 0.32: 0.88$ \\
\hline NPKMgS & 375 & 120 & 330 & $1: 0.32: 0.88$ \\
\hline NPK $2 M g S$ & 375 & 120 & 660 & $1: 0.32: 1.76$ \\
\hline NPK $3 g$ M & 375 & 120 & 990 & $1: 0.32: 2.64$ \\
\hline
\end{tabular}

* The chemical fertilizers were applied as urea, superphosphate, calcium magnesium phosphate, diammonium phosphate, kieserite $\left(\mathrm{MgSO}_{4}\right)$ and potassium chloride.

Nutrient contents in the fertilizers was as follows:

Calcium magnesium phosphate (CMP) : $\mathrm{P}_{2} \mathrm{O}_{5} 14 \%$, MgO $18 \%$; Single superphosphate (SSP): $\mathrm{P}_{2} \mathrm{O}_{5} 14 \%$, S $14 \%$; kieserite $\left(\mathrm{MgSO}_{4}\right)$ : $\mathrm{MgO} 16 \%$, S 13 \%; Diammonium phosphate (DAP): $\mathrm{P}_{2} \mathrm{O}_{5} 46$ \%, N $18 \%$; Urea: N 46 \%; KCl: $\mathrm{K}_{2} \mathrm{O} 60 \%$.

The application fertilizer: $\mathrm{N}$ and $\mathrm{K}$ were applied in four splits (5\%, $15 \%, 25 \%$ and $50 \%)$ at the basal dressing, seeding, tillering and cane elongation stage. Other fertilizers were applied as basal application.

Four replications were used for each trial. The plot area was 33.3 square meters.

\section{Plant density and variety}

Plant density was 65,000 buds/ha. The variety of sugarcane was guitang and taitang series.

\section{Soil analysis methods}

The total $\mathrm{K}$ in soil was heated and melted with carbonate sodium $\left(\mathrm{Na}_{2} \mathrm{CO}_{3}\right)$. The slow-release soil available $\mathrm{K}$ was extracted by nitric acid $\left(1 \mathrm{~N} \mathrm{HNO}_{3}\right)$, then heated and boiled for $10 \mathrm{~min}$. The soil available $\mathrm{K}$ was extracted by ammonium of acetic acid. Then, the amount was determined using a flame-spectrum meter.

For the total $\mathrm{P}$ soil analysis, $\mathrm{NaOH}$ was added to the sample and heated at $720{ }^{\circ} \mathrm{C}$ for 5 minutes. To analyze the available $\mathrm{P}$, the sample was extracted by $0.5 \mathrm{M} \mathrm{NaHCO}_{3}$, and the amount determined by a photometer.

Soil $\mathrm{pH}$ was measured in a soil to water ratio of $1: 2.5$ with a $\mathrm{pH}$ meter. Total $\mathrm{N}$ in soils was determined by the microKjeldahl method. Exchangeable $\mathrm{Mg}$ and $\mathrm{K}$ was determined with atomic absorption spectrophotometry by extracting the soil with a $1 \mathrm{~N} \mathrm{NH}_{4} \mathrm{OAc}$ solution in a $1: 10$ soil : solution ratio.

To determine $\mathrm{S}$ in the soil, the $\mathrm{Ca}\left(\mathrm{H}_{2} \mathrm{PO}_{4}\right)_{2}$ extraction method was used.

\section{$\mathrm{N}, \mathrm{P}_{2} \mathrm{O}_{\mathbf{5}}$ and $\mathrm{K}_{\mathbf{2}} \mathrm{O}$ of sugarcane stalk and leave}

Total N, P and $\mathrm{K}$ were determined by the $\mathrm{K}_{2} \mathrm{Cr}_{2} \mathrm{O}_{7}+\mathrm{H}_{2} \mathrm{SO}_{4}$ digestion method, the $\mathrm{H}_{2} \mathrm{SO}_{4}+\mathrm{HClO}_{4}$-molybdenum blue method, and $\mathrm{CaCO}_{3}+\mathrm{NH}_{4} \mathrm{Cl}$ fusion-flame photometric method, respectively.

Total $\mathrm{S}$ in plants was determined by the $\mathrm{HNO}_{3}+\mathrm{HClO}_{4}$ boil method.

\section{Analysis of sugarcane quality}

Sugar was determined using the revolving light meter. Reducing sugar was determined using the filin-iodine volumetric procedure.

Fiber was determined using the method of acid-detergent fiber. 
Application of "a systematic approach for soil fertility evaluation" to determine the limit responses of the plant nutrients being tested

This technique involved seven steps: obtaining the soil sample, preparing the soil sample, analyzing the sample in the laboratory, determining amounts to be used for optimum treatment, preparing and applying the treatments, potting and planting the soil, and harvesting (Hunter, 1975). Collection of the soil sample: for the first 10-15 trials, bulk soil samples of $50 \mathrm{~kg}$ were collected in clean plastic bags. Preparation of soil sample: drying after stones and organic debris were removed from the sample. Analysis of the sample in laboratory: physical and chemical analysis, and chemical analysis included the routine soil analysis and "fixation" analysis. Determining amounts of amendments to be applied to the optimum treatment: optimum treatment was determined according to the results of analysis in laboratory. Preparing and applying the treatments: OPT, $-\mathrm{N},-\mathrm{P},-\mathrm{K},-\mathrm{S}$ and $-\mathrm{Mg}$ etc. treatments were included. Potting and planting the soil: the soil for each pot was measured by weight. The small pots were marked with their treatment and replication number. Planting test crop (corn). Harvesting: at the end of the optimum growth period, obvious growth differences were observed for some treatments, but other treatments appeared to have growth equal to, or possibly even greater than, the optimum treatment. The nutrient supply of the soil will be enough in N, P, K, S and Mg.

\section{RESULTS AND DISCUSSION}

\section{Chemical properties of the tested soils}

Availability and utilization by plants of essential nutrients in the soil is affected by the soil's physical and chemical characteristics, plant characteristics, and other factors affecting plant growth, such as temperature, moisture, light, etc. The agrochemical properties of the tested soils are given in Table 2.

Table 2. Chemical properties of the tested soils

\begin{tabular}{|l|l|l|l|l|l|l|l|l|}
\hline Field site & $\mathrm{pH}$ & O.M. (\%) & $\begin{array}{l}\text { Avail.N } \\
(\mathrm{ppm})\end{array}$ & $\begin{array}{l}\text { Avail.P } \\
(\mathrm{ppm})\end{array}$ & $\mathrm{K}(\mathrm{ppm})$ & $\begin{array}{l}\text { Avail. S } \\
(\mathrm{ppm})\end{array}$ & $\begin{array}{l}\text { Avail.B } \\
(\mathrm{ppm})\end{array}$ & $\begin{array}{l}\text { Avail.Mg } \\
(\mathrm{ppm})\end{array}$ \\
\hline Nanning & 5.0 & 2.19 & 47.4 & 11.6 & 43.0 & 18.8 & 0.21 & 62.0 \\
\hline Laibin & 6.8 & 1.58 & 13.7 & 14.5 & 70.4 & 8.0 & 0.24 & 100.5 \\
\hline
\end{tabular}

\section{Pot culture trial}

The relative (\%) yield was less than 100. This means the individual treatment average yield was less than the optimum. All treatment yields were significantly lower than the optimum treatment. Low levels of nitrogen, phosphate, potassium, sulphur and magnesium limited crop growth. The results obtained from the pot culture trial indicated that the two soils tested were poor in nitrogen, phosphate, potassium, magnesium and sulphur (Table 3).

Table 3. Results of pot culture trial

\begin{tabular}{|l|l|l|l|l|}
\hline \multirow{2}{*}{ Treatments } & \multicolumn{2}{|l|}{ Nanning suburb } & \multicolumn{2}{l|}{ Laibin Qiaogong } \\
\cline { 2 - 5 } & Dry matter yield (g/pot) & Relative yield (\%) & Dry matter yield (g/pot) & Relative yield (\%) \\
\hline OPT & 5.65 & 100 & 7.76 & 100 \\
\hline$-\mathrm{N}$ & $2.23^{* *}$ & 39.5 & $3.21^{* *}$ & 41.3 \\
\hline$-\mathrm{P}$ & $2.87^{* *}$ & 50.8 & $6.09^{* *}$ & 78.5 \\
\hline$-\mathrm{K}$ & $2.50^{* *}$ & 44.3 & $4.53^{* *}$ & 58.4 \\
\hline$-\mathrm{Mg}$ & $5.02^{*}$ & 88.9 & $6.16^{* *}$ & 79.4 \\
\hline$-\mathrm{S}$ & $5.21^{*}$ & 92.1 & $6.56^{*}$ & 84.6 \\
\hline
\end{tabular}

Note $\quad: \mathrm{F}=564.42$, LSD $0.05=0.144$, LSD $0.01=0.199$

Significance level: *P < LSD 0.05; * ${ }^{*}$ < LSD 0.01 . 


\section{Influence of various treatments on sugarcane growth}

Increasing potassium, magnesium and sulphur fertilizer can increase plant height (Xie et al., 1991; Morris, 1990). In July and August, potassium, potassium and magnesium, and potassium, magnesium and sulphur fertilizer treatments increased plant height by $0.8-11.4 \mathrm{~cm}$ and $4-26.6 \mathrm{~cm}$ and $20-21.3 \mathrm{~cm}$ more than the treatment of $\mathrm{NPK}_{0}$, respectively (Table 4).

Table 4. Influences of various treatments on plant height

\begin{tabular}{|l|l|l|l|}
\hline Treatment & Plant height $(\mathrm{cm})$ July 31 & Plant height $(\mathrm{cm})$ August 8 & Plant height (cm) August 21 \\
\hline $\mathrm{NPK}_{0}$ & 167.5 & 197.4 & 217.0 \\
\hline $\mathrm{NPK}_{1}$ & $178.9^{* *}$ & $203.4^{* *}$ & $232.0^{* *}$ \\
\hline $\mathrm{NPK} M g$ & $173.6^{*}$ & $204.6^{* *}$ & 221.0 \\
\hline $\mathrm{NPK} M g S$ & 168.3 & $206.0^{* *}$ & $226.5^{* *}$ \\
\hline $\mathrm{NPK}_{2} \mathrm{MgS}$ & 170.3 & $218.7^{* *}$ & $237.0^{* *}$ \\
\hline $\mathrm{NPK}_{3} \mathrm{MgS}$ & $173.3^{*}$ & $209.7^{* *}$ & $243.6^{* *}$ \\
\hline
\end{tabular}

Note $\quad: \mathrm{F}=96.49$, LSD $0.05=5.379$, LSD $0.01=8.653$

Significance level: ${ }^{*} \mathrm{P}<$ LSD $0.05 ;{ }^{*} \mathrm{P}<$ LSD 0.01 .

\section{The effect of potassium, magnesium and sulphur applications on sugarcane yield}

\section{Effect of potassium, magnesium and sulphur applications on sugarcane yield}

The influence of potassium, magnesium and sulphur on biological and yield properties of sugarcane is presented in Table 5. The application of Mg-fertilizer increased single stem weight by 104 grams (an increase rate of $9.44 \%$ ) in Nanning and by 27 grams (an increase rate of $1.49 \%$ ) in Laibin. On the basis of applied Mg-fertilizer, application of S-fertilizer increased single stem weight, and the biggest increase rate reached was $4.47 \%$ in Nanning. The effect of K on sugarcane yield was mainly due to the increase in the number of available stems. In addition, the application of $\mathrm{K}, \mathrm{Mg}$ and $\mathrm{S}$ also increased the stem diameter and plant height of sugarcane.

Table 5. Influence of $\mathrm{K}, \mathrm{Mg}$ and $\mathrm{S}$ on biological and yield properties of sugarcane

\begin{tabular}{|c|c|c|c|c|c|c|c|}
\hline \multicolumn{2}{|c|}{ Treatments } & $\mathrm{NPK}_{0}$ & $\mathrm{NPK}_{1}$ & $\mathrm{NPK}_{1} \mathrm{Mg}$ & NPKıMgS & $\mathrm{NPK}_{2} \mathrm{MgS}$ & $\mathrm{NPK}_{3} \mathrm{MgS}$ \\
\hline \multirow[t]{3}{*}{ Nanning } & Single stem weight (g) & 1009 & $1102^{* *}$ & $1206^{* *}$ & $1260^{* *}$ & $1261^{* *}$ & $1243^{* *}$ \\
\hline & Diameter of stem (mm) & 23.6 & $24.2^{*}$ & $24.6^{*}$ & $24.9^{*}$ & $24.9^{*}$ & $25.1^{* *}$ \\
\hline & Available stem per ha & 61800 & $61995^{*}$ & 60240 & 58320 & $63705^{* *}$ & 59145 \\
\hline \multirow[t]{3}{*}{ Laibin } & Single stem weight (g) & 1770 & $1810^{* *}$ & $1837^{* *}$ & $1850^{* *}$ & $1910^{* *}$ & $1815^{* *}$ \\
\hline & Diameter of stem (mm) & 26.3 & $27.3^{*}$ & $27.6^{*}$ & $27.8^{*}$ & $28.0^{*}$ & $27.9^{*}$ \\
\hline & Available stem per hectare & 40695 & $43500^{*}$ & $44745^{*}$ & $43245^{*}$ & $46275^{*}$ & $44250^{*}$ \\
\hline
\end{tabular}

Note : ${ }^{*}$ In comparison with $\mathrm{NPK}_{0}(\mathrm{CK})$, reached at 0.10 significant level.

** In comparison with $\mathrm{NPK}_{0}(\mathrm{CK})$, reached at 0.05 significant level.

As for the influence of potassium, magnesium and sulphur on yield of sugarcane, among all treatments, $\mathrm{NPK}_{2} \mathrm{MgS}$ achieved the highest yield of sugarcane (Table 6). In Nanning, $\mathrm{NPK}_{2} \mathrm{MgS}$ reached $78756.1 \mathrm{~kg} / \mathrm{ha}$, which was 12635.6 $\mathrm{kg} / \mathrm{ha}$ more than the $\mathrm{NPK}_{0}$ treatment and with an increase rate of $19.1 \%$; in Laibin, $\mathrm{NPK}_{2} \mathrm{MgS}$ reached $99904.7 \mathrm{~kg} / \mathrm{ha}$, which was $19195.3 \mathrm{~kg} / \mathrm{ha}$ more than the $\mathrm{NPK}_{0}$ treatment and with an increase rate of $23.8 \%$, and the difference was very significant. Applied K-fertilizer increased the sugarcane yield $4.8 \%$ more than the $\mathrm{NPK}_{0}$ treatment in Nanning and $8.6 \%$ more in Laibin. On the basis of $\mathrm{NPK}_{1} \mathrm{Mg}$, applied S-fertilizer, sugarcane yield increased $3.6 \%$ in Nanning, and $2.8 \%$ in Laibin. With equal $\mathrm{Mg}$ and $\mathrm{S}$, different performances at the two trial sites were observed. At the Nanning site, applied S 
and $\mathrm{Mg}$-fertilizer showed the best effect, and sugarcane yield increased $4.9 \%$ more than the $\mathrm{NPK}_{1}$ treatment; while at the Laibin site, applied S and Mg-fertilizer got the best effect, and the sugarcane yield increased by $5.7 \%$ more than the $\mathrm{NPK}_{1}$ treatment. With $\mathrm{NPK}_{1} \mathrm{MgS}$, potassium application with $\mathrm{NPK}_{2} \mathrm{MgS}$ treatments increased sugarcane yield by $8.5 \%$ more than $\mathrm{NPK}_{1} \mathrm{MgS}$ at the Nanning site, and $7.9 \%$ more at the Laibin site. The $\mathrm{NPK}_{2} \mathrm{MgS}$ treatment was best for increasing sugarcane yield. As for the effect of $\mathrm{K}, \mathrm{Mg}$ and $\mathrm{S}$ on sugarcane yield, the application of $\mathrm{K}$ got the best effect, and the application of $\mathrm{Mg}$ and $\mathrm{S}$ also variously affected yield. The treatment with $\mathrm{NPK}_{2} \mathrm{MgS}$ was best for sugarcane yield in both trials.

Table 6. Yield analysis of various treatments

\begin{tabular}{|c|c|c|c|c|c|c|c|}
\hline \multicolumn{2}{|c|}{ Treatments } & $\mathrm{NPK}_{0}$ & $\mathrm{NPK}_{1}$ & $\mathrm{NPK}_{1} \mathrm{Mg}$ & NPKıMgS & $\mathrm{NPK}_{2} \mathrm{MgS}$ & $\mathrm{NPK}_{3} \mathrm{MgS}$ \\
\hline \multirow[t]{3}{*}{ Nanning } & Two year average yield (kg/ha) & \multirow[t]{3}{*}{66120.5} & 69260.2 & 70037.6 & 72583.8 & 78756.1 & 72984.8 \\
\hline & Increase over $\mathrm{NPK}_{0}(\mathrm{~kg} / \mathrm{ha})$ & & $3139.7^{*}$ & $3917.1^{*}$ & $6463.3^{* *}$ & $12635.6^{* *}$ & $6864.3^{* *}$ \\
\hline & Increase over NPKo (\%) & & 4.8 & 5.9 & 9.8 & 19.1 & 10.4 \\
\hline \multirow[t]{3}{*}{ Laibin } & Two year average yield $(\mathrm{kg} / \mathrm{ha})$ & \multirow[t]{3}{*}{80709.4} & 87646.9 & 90103.2 & 92599.1 & 99904.7 & 91453.5 \\
\hline & Increase over NPKo $(\mathrm{kg} / \mathrm{ha})$ & & $6937.5^{*}$ & $9393.8^{* *}$ & $11889.7^{* *}$ & $19195.3^{* *}$ & $10744.1^{* *}$ \\
\hline & Increase over $\mathrm{NPK}_{0}(\%)$ & & 8.6 & 11.6 & 14.7 & 23.8 & 13.3 \\
\hline \multicolumn{2}{|c|}{ Two sites average yield (kg/ha) } & 73415.0 & 78453.6 & 80070.4 & 82591.5 & 89330.4 & 82219.2 \\
\hline \multicolumn{2}{|c|}{ Increase over $\mathrm{NPK}_{0}(\mathrm{~kg} / \mathrm{ha})$} & & $5038.6^{*}$ & $6655.4^{* *}$ & $9176.5^{* *}$ & $15915.4^{* *}$ & $8804.2^{* *}$ \\
\hline \multicolumn{2}{|c|}{ Increase over NPKo (\%) } & & 6.86 & 9.07 & 12.50 & 21.68 & 11.99 \\
\hline
\end{tabular}

Note: $\mathrm{F}=68.39$, LSD $0.05=1.179$, LSD $0.01=1.653$

* In comparison with NPK $(\mathrm{CK})$, reached at 0.10 significant level.

** In comparison with $\mathrm{NPK}_{0}(\mathrm{CK})$, reached at 0.05 significant level.

\section{Economic analysis}

The results of Table 7 show that the $\mathrm{NPK}_{2} \mathrm{MgS}$ treatment obtained the highest net income of $2121.7 \mathrm{RMB} / \mathrm{ha}$ in Nanning, and 3827.2 RMB/ha in Laibin. The application of magnesium increased net income to $693.1 \mathrm{RMB} / \mathrm{ha}$ in Nanning and 1680.6 RMB/ha in Laibin. All combined applications of S and Mg increased net income. Among the various combinations of $\mathrm{S}$ and $\mathrm{Mg}$, the application of $\mathrm{NPK}_{2} \mathrm{MgS}$ garnered the highest net income of $1345.4 \mathrm{RMB} / \mathrm{ha}$ in Nanning, which was 652.2 $\mathrm{RMB} /$ ha more than with only $\mathrm{Mg}$-fertilizer treatment and the application $\mathrm{NPK}_{2} \mathrm{MgS}$ garnered the highest net income of $2210.4 \mathrm{RMB} /$ ha in Laibin, which was $529.8 \mathrm{RMB} /$ ha more than with only Mg-fertilizer treatment. On the basis of $\mathrm{NPK}_{1} \mathrm{MgS}$, applied potassium increased net income to $776.3 \mathrm{RMB} /$ ha in Nanning and 2510.9 RMB/ha in Laibin. Concerning the ratio of output/input, the $\mathrm{NPK}_{1} \mathrm{Mg}$ treatment had the highest ratio at the two trial sites.

Table 7. Economic benefit of $\mathrm{K}, \mathrm{Mg}$ and $\mathrm{S}$ application on sugarcane

\begin{tabular}{|c|c|c|c|c|c|c|c|}
\hline \multicolumn{2}{|c|}{ Treatments } & \multirow{2}{*}{$\begin{array}{l}\mathrm{NPK}_{0} \\
66120.5\end{array}$} & \multirow{2}{*}{$\begin{array}{l}\mathrm{NPK}_{1} \\
69260.2\end{array}$} & \multirow{2}{*}{$\begin{array}{c}\mathrm{NPK}_{1} \mathrm{Mg} \\
70037.6\end{array}$} & \multirow{2}{*}{$\begin{array}{c}\text { NPKiMgS } \\
72583.8\end{array}$} & \multirow{2}{*}{$\begin{array}{c}\mathrm{NPK}_{2} \mathrm{MgS} \\
78756.1\end{array}$} & \multirow{2}{*}{$\begin{array}{c}\mathrm{NPK}_{3} \mathrm{MgS} \\
72984.8\end{array}$} \\
\hline Nanning & Yield (kg/ha) & & & & & & \\
\hline & Total output (RMB/ha) & 17191.3 & 18007.7 & 18209.8 & 18871.8 & 20476.6 & 18976.1 \\
\hline & Fertilizer input (RMB/ha) & 2941.3 & 3064.4 & 3173.3 & 3279.8 & 4104.8 & 3785.9 \\
\hline & Amount output more than NPKo (RMB/ha) & & $816.3^{* *}$ & $1018.5^{* *}$ & $1680.5^{* *}$ & $3285.3^{* *}$ & $1784.7^{* *}$ \\
\hline & Amount input more than NPKo $(\mathrm{RMB} / \mathrm{ha})$ & & 123.2 & 232.1 & 335.1 & 1163.6 & 844.7 \\
\hline \multirow[t]{2}{*}{ Laibin } & Yield (kg/ha) & 80709.4 & 87646.9 & 90103.2 & 92599.1 & 99904.7 & 91453.5 \\
\hline & Total output (RMB/ha) & 20984.4 & 22788.2 & 23426.8 & 24075.7 & 25975.2 & 23777.9 \\
\hline
\end{tabular}




\begin{tabular}{|l|l|l|l|l|l|l|l|}
\hline Fertilizer input (RMB/ha) & 2941.3 & 3064.4 & 3173.3 & 3279.8 & 4104.8 & 3785.9 \\
\cline { 2 - 8 } & Amount output more than NPK $(\mathrm{RMB} / \mathrm{ha})$ & & $1803.8^{* *}$ & $2442.4^{* *}$ & $3091.3^{* *}$ & $4990.8^{* *}$ & $2793.5^{* *}$ \\
\cline { 2 - 7 } & Amount input more than NPKo (RMB/ha) & & 123.2 & 232.1 & 335.1 & 1163.6 & 844.7 \\
\hline
\end{tabular}

Note: ${ }^{*}$ In comparison with $\mathrm{NPK}_{0}(\mathrm{CK})$, reached at 0.10 significant level.

** In comparison with $\mathrm{NPK}_{0}(\mathrm{CK})$, reached at 0.05 significant level.

Influence of potassium, magnesium and sulfur application on sugarcane quality

As for the influence of potassium, magnesium and sulfur on the quality of sugarcane, the results in Table 8 show that the treatments with potassium, magnesium and sulfur fertilizer increased the sucrose content of sugarcane significantly. Increased use of potassium, magnesium and sulfur fertilizer increased the content of fiber in sugarcane as well. In addition, the application of $\mathrm{Mg}$-fertilizer decreased sugar content significantly. A higher potassium application rate had no significant influence on the quality of sugarcane.

Table 8. Influence of potassium, magnesium and sulfur on the quality of sugarcane

\begin{tabular}{|l|l|l|l|l|l|l|}
\hline Treatment & $\mathrm{NPK}_{0}$ & $\mathrm{NPK}_{1}$ & $\mathrm{NPK} 1 \mathrm{Mg}$ & $\mathrm{NPK} \mathrm{MgS}$ & $\mathrm{NPK}_{2} \mathrm{MgS}_{3}$ & $\mathrm{NPK}_{3} \mathrm{MgS}$ \\
\hline Sucrose (\%) & 13.60 & $14.88^{*}$ & $14.95^{*}$ & $14.41^{*}$ & $13.86^{*}$ & $15.30^{*}$ \\
\hline Fiber (\%) & 11.26 & 11.54 & 11.56 & 11.46 & 11.57 & 11.42 \\
\hline Reducing (\%) & 2.38 & 2.44 & 1.71 & 2.16 & 2.14 & 2.26 \\
\hline
\end{tabular}

Note: ${ }^{*}$ In comparison with $\mathrm{NPK}_{0}(\mathrm{CK})$, reached at 0.10 significant level.

** In comparison with NPK $(\mathrm{CK})$, reached at 0.05 significant level.

\section{Potassium requirement of sugarcane}

Sugarcane, a grass family crop, has favorable growth in tropical and sub-tropical regions. Its biomass production is 60180 tons per hectare, and is one of the high yield crops. As sugarcane's biomass production increases, it absorbs more and more nutrition (Zhang et al., 1998). In general, sugarcane absorbs 109.1-315.28 kg per hectare of $\mathrm{K}_{2} \mathrm{O}$..

According to the statistical results of 22 field experiments, the relationship of sugarcane yield to sugarcane absorbing potassium amount was positively correlated (Fig. 1). The correlation coefficient was $r=0.979^{* *}$, a remarkable

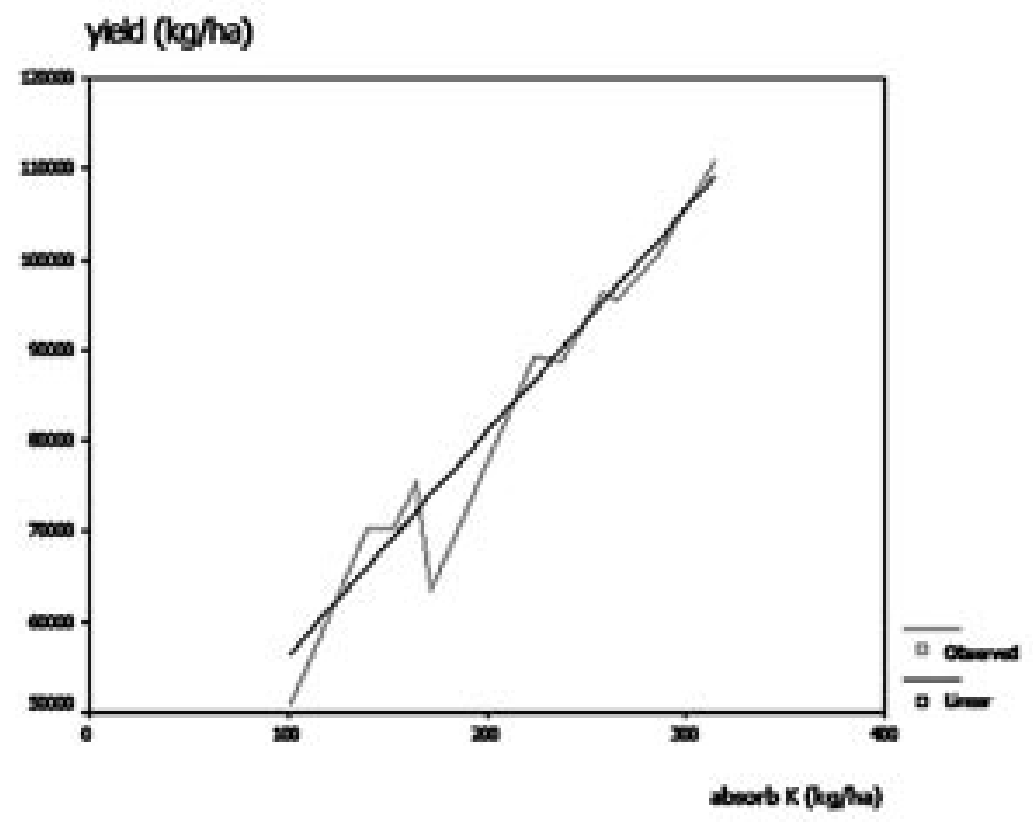

Fig. 1. Relationship between yield and amount of potassium absorbed 
level. The function of the sugarcane yield (y) with the amount of potassium sugarcane absorbs ( $\mathrm{x}$ ) was $\mathrm{y}=31687.1+24.6 \mathrm{x}$.

Most crops absorb more potassium than other nutrients in the tropical and sub-tropical crop planting region. For example, both banana and sugarcane absorb more potassium than nitrogen and phosphorus. (Zhang et al., 1998) The amount of potassium absorbed in sugarcane increased with increasing yield.

\section{Soil potassium classification of sugarcane planting regions}

\section{Soil available potassium is a critical value in sugarcane planting regions}

The availability of soil potassium is influenced by soil texture and soil moisture etc. Soil and plant interactions create a dynamic system. In addition, a soil's supply of potassium for crop nutrition is determined by complicated processes. According to the results of field experiments in Nanning and Laibin, the relationship between soil available potassium and crop yield determines the soil potassium critical value.

For the field experiment on potassium application in Nanning and Laibin, the soil texture was classified as either sandy, loamy or clayey. A dispersion map was made with sugarcane yield of NP treatment on the y axis and available potassium content on the $\mathrm{x}$ axis with soil. According to the relationship between sugarcane yield and soil available potassium content, the correlation coefficient and curve equation were determined. The curve equation was applied to calculate the soil available potassium content (soil available potassium critical value) under certain objective yields with a confidence interval of $95 \%$.

(a). Sandy soil available potassium critical value

As for the statistical results of the 8 field experiments for the sandy soil group of Nanning and Laibin, the sugarcane yield of NP treatment and the soil available potassium content had outstanding positive correlation, $\mathrm{r}=0.994^{* *}$ (Correlation function: $y=-78606+3747.2 x-15 x^{2}$, (Fig. 2)). According to the correlation function of sugarcane yield with soil available potassium content, when the yield desired was $60,000 \mathrm{~kg} / \mathrm{ha}$ (the average yield level of sugarcane in sandy soil of Guangxi), the sandy soil available potassium critical value was $46.2 \mathrm{mg} / \mathrm{kg}$.

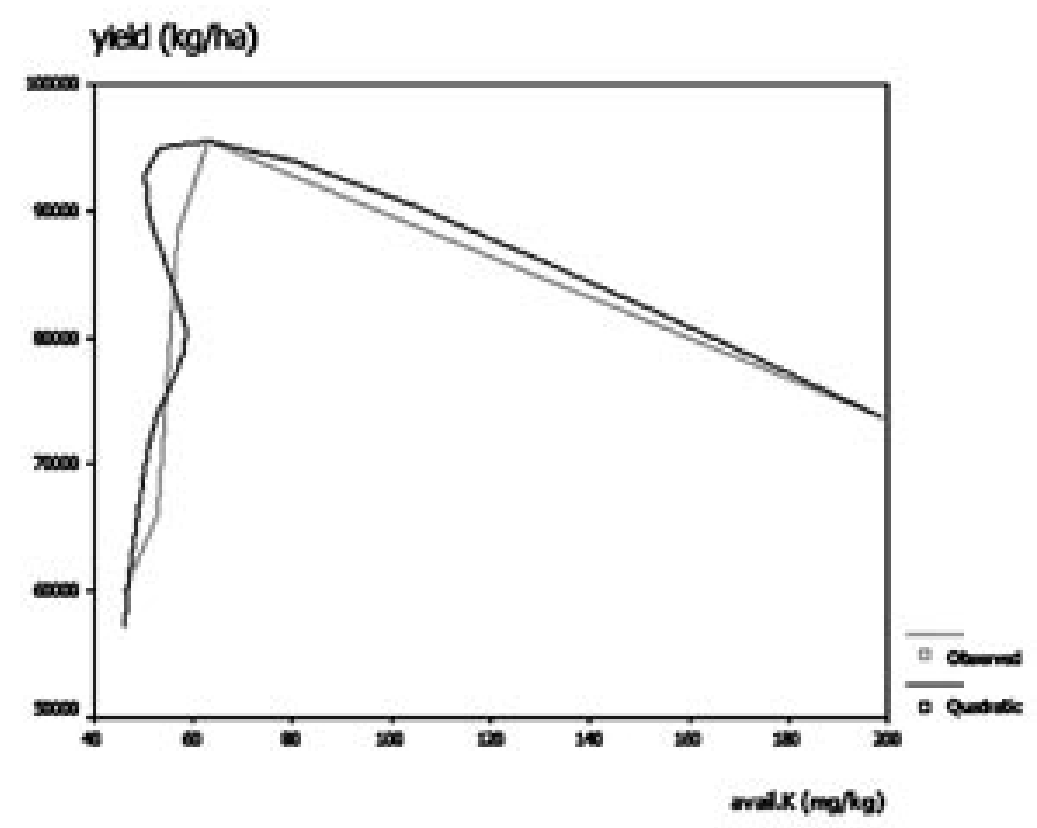

Fig. 2. Relationship between sugarcane yield and soil available potassium content in sandy soil

(b). Loamy soil available potassium critical value

The statistical results of the 15 field experiments in the loamy soil group of Nanning and Laibin, indicated that the sugarcane yield of NP treatment and the soil available potassium content had a significant positive correlation, $r=0.803^{* *}$ (the correlation function: $\mathrm{y}=12653.2+1154.3 \mathrm{x}-3.4 \mathrm{x}^{2}$, (Fig. 3)). According to the correlation function, when the yield desired was $63,000 \mathrm{~kg} / \mathrm{ha}$ (the average yield in loamy and clayey soil of Guangxi), the soil available potassium content (x) was $51.4 \mathrm{mg} / \mathrm{kg}$. 


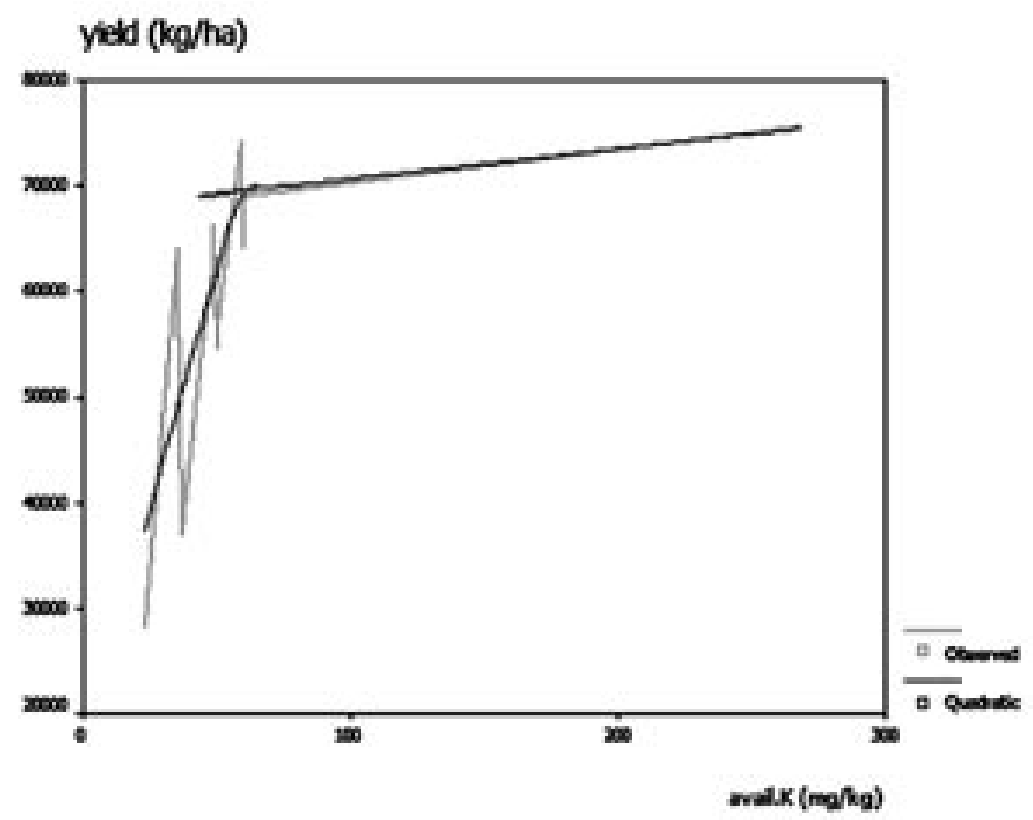

Fig. 3. Relationship between sugarcane yield and soil available potassium content in loamy soil

(c). Clayey soil available potassium critical value

The statistical results of the 59 field experiments in clayey soil group of Nanning and Laibin, showed that the sugarcane yield of NP treatment and the soil available potassium content had significant positive correlation, $r=0.853^{* *}$. The correlation function of sugarcane yield ( $\mathrm{y}$ ) with soil available potassium content ( $\mathrm{x}$ ) is $\mathrm{y}=57904.8-311.1 \mathrm{x}+6.6 \mathrm{x}^{2}$, (Fig. 4). According to the calculation of correlation function, when the yield desired was $63,000 \mathrm{~kg} / \mathrm{ha}$, the soil available potassium content (x) was $60 \mathrm{mg} / \mathrm{kg}$.

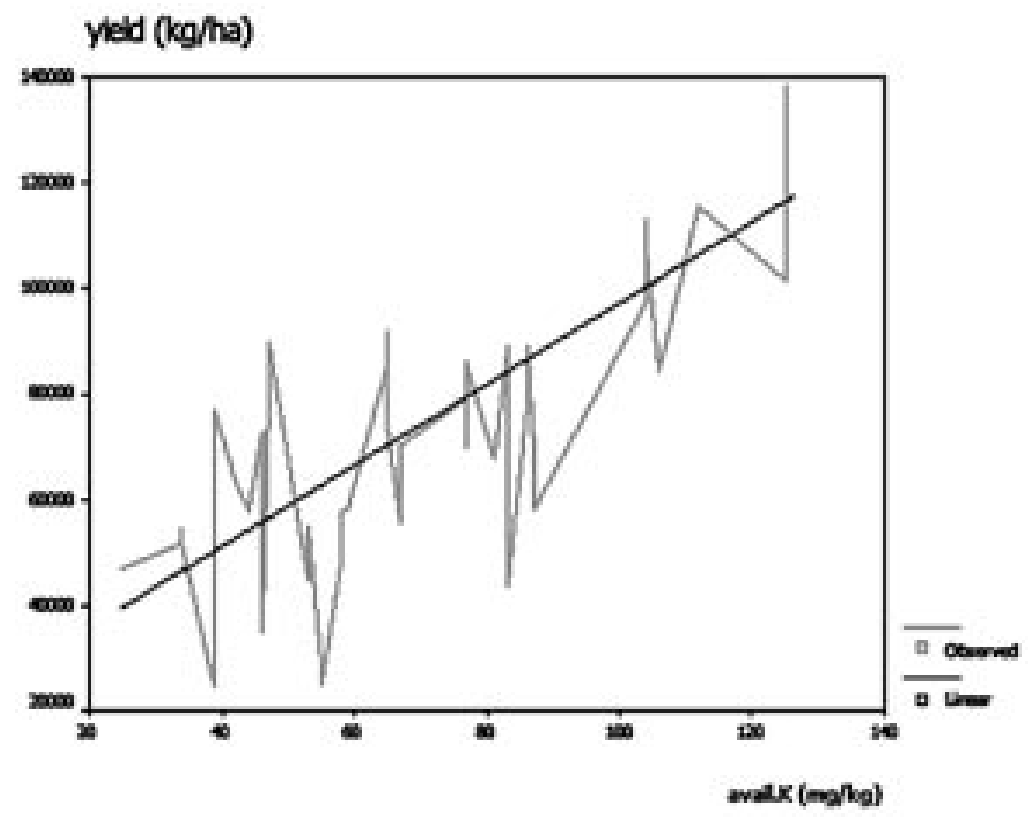

Fig. 4. Relationship between sugarcane yield and soil available potassium content in clayey soil

It is clear that as soil clay content increased, the soil available potassium critical value also increased.

In addition, the soil's supply of potassium for crop nutrition is a complicated process. To study the soil potassium critical value we investigated the soil available potassium content in different soil textures when sugarcane yield was at an average yield level. Field experiment results were used to determine the relationship between soil available potassium 
and crop yield. From that relationship the soil potassium critical value was calculated.

\section{Classification of soil available potassium in sugarcane planting region}

The soil available potassium was classified according to the yield production level of sugarcane and the effect of application potassium fertilizer. Sugarcane response to potassium as affected by the potassium status (available potassium including soluble potassium and exchangeable potassium) was measured and statistically analysed. Calculated critical values depended on the soil texture, characterised as sands, loam soils and clays. For sugarcane which is cultivated on all three soil textures, the calculated critical potassium values were, 46,52 and $60 \mathrm{mg} \mathrm{kg}^{-1}$ of exchangeable potassium in sandy, loamy and clayey soils, respectively. Accordingly, potassium supply classes for soils, growing sugarcane, were established. For the three soil textures the following supply classes were defined: 1 . Low potassium supply: < $46 \mathrm{mg} \mathrm{kg}^{-1},<52 \mathrm{mg} \mathrm{kg}{ }^{-1}$ and $<60 \mathrm{mg} \mathrm{kg}{ }^{-1}, 2$. Medium potassium supply: 46-90 mg kg-1, 52-110 mg kg $\mathrm{kg}^{-1}$ and 60-120 mg kg-1 . 3. High potassium supply: $>90 \mathrm{mg} \mathrm{kg}^{-1}$, > $110 \mathrm{mg} \mathrm{kg}^{-1}$ and $>120 \mathrm{mg} \mathrm{kg}^{-1}$, for sandy, loamy and clayey soils, respectively. The results from Table 9 indicated that the effect of potassium in various soil available potassium on the yield of sugarcane was very significant. Increase rate were ranged from $5 \%$ to $18 \%$. For example, the statistical results of applying potassium fertilizer in sugarcane planting regions of sandy soil, when soil available potassium content was lower than $46 \mathrm{mg} / \mathrm{kg}$, the sugarcane with applied potassium fertilizer increased in yield more than $18 \%$ (increasing sugarcane yield of $113 \mathrm{~kg}$ per $\mathrm{kg} \mathrm{K}_{2} \mathrm{O}$ ). The soil available potassium was $46-90 \mathrm{mg} / \mathrm{kg}$ and the sugarcane yield when potassium fertilizer was applied increased more than $15 \%$ (increasing sugarcane yield of $91 \mathrm{~kg}$ per $\mathrm{K}_{2} \mathrm{O}$ ). In sugarcane planting regions of loamy soil, when soil available potassium content was lower than $52 \mathrm{mg} / \mathrm{kg}$, indicated that when the sugarcane potassium fertilizer application increased more than 15 \%(increasing sugarcane yield of $109.2 \mathrm{~kg}$ per $\mathrm{kg} \mathrm{K}_{2} \mathrm{O}$ ). The soil available potassium content was $52-110 \mathrm{mg} / \mathrm{kg}$ and the sugarcane of application potassium fertilizer the increase rate was $10 \%$ and increased the yield of $88 \mathrm{~kg}$ per $\mathrm{kg} \mathrm{K} \mathrm{K}_{2} \mathrm{O}$. In sugarcane planting regions of clay soil, the soil available potassium was $60 \mathrm{mg} / \mathrm{kg}$, the increase rate of application potassium fertilizer on sugarcane was more $10 \%$. When soil available potassium content was $60-120 \mathrm{mg} / \mathrm{kg}$, the rate of application potassium fertilizer on sugarcane was $5-10 \%$ and increased the yield of $67.2 \mathrm{~kg}$ per $\mathrm{kg} \mathrm{K} \mathrm{K}_{2} \mathrm{O}$. When soil available potassium content was more $120 \mathrm{mg} / \mathrm{kg}$, the rate of application potassium fertilizer on sugarcane was lower than $5 \%$ and increased the yield of $8 \mathrm{~kg} \mathrm{per} \mathrm{kg} \mathrm{K}_{2} \mathrm{O}$.

Table 9. The soil available potassium classify of sugarcane planting region

\begin{tabular}{|c|c|c|c|c|}
\hline Crop & Texture & Soil available $\mathrm{K}(\mathrm{mg} / \mathrm{kg})$ & Increased yield $\mathrm{kg}$ per $\mathrm{K}_{2} \mathrm{O} \mathrm{kg}$ & $(\%)$ \\
\hline \multirow[t]{9}{*}{ sugarcane } & \multirow[t]{3}{*}{ Sandy } & $<46$ & $113.0^{* *}$ & $>18^{* *}$ \\
\hline & & $46 \sim 90$ & $91^{* *}$ & $13.3^{* *}$ \\
\hline & & $>90$ & - & - \\
\hline & \multirow[t]{3}{*}{ Loam } & $<52$ & $109.2^{* *}$ & $>15^{* *}$ \\
\hline & & $52 \sim 110$ & $88^{* *}$ & $10^{* *}$ \\
\hline & & $>110$ & - & - \\
\hline & \multirow[t]{3}{*}{ Clay } & $<60$ & $139.7^{* *}$ & $>10^{* *}$ \\
\hline & & $60 \sim 120$ & $67.2^{*}$ & $7.5^{*}$ \\
\hline & & $>120$ & $<8$ & $<5$ \\
\hline
\end{tabular}

Note: ${ }^{*}$ In comparison with NPK $(\mathrm{CK})$, reached at 0.10 significant level.

** In comparison with NPK $(\mathrm{CK})$, reached at 0.05 significant level.

\section{CONCLUSION}

In Guangxi, significant amounts of potassium are absorbed by sugarcane, banana and pineapples. However, soil available potassium content was low. So, a classification system of soil available K, with special consideration for tropic and sub- 
tropic crops, was created as shown:

(1) The potassium requirement of sugarcane was more than other crops and sugarcane's requirement for potassium was more than that of its need for nitrogen and phosphorus. Sugarcane absorbs $100.91-315.28 \mathrm{~K}_{2} \mathrm{O} \mathrm{kg}$ per hectare. The relationship between sugarcane yield $(\mathrm{x})$ and potassium absorbed by sugarcane (y) was $\mathrm{y}=31687.1+24.6 \mathrm{x}, \mathrm{r}=0.979 * *$.

(2) The classification system of soil available potassium in sugarcane planting regions in sandy soil indicated that the available potassium critical value was $46.2 \mathrm{mg} / \mathrm{kg}$. The function of sugarcane yield (y) with soil available potassium (x) was $\mathrm{y}=-78606+3747.2 \mathrm{x}-15 \mathrm{x}^{2}, \mathrm{r}=0.994^{* *}$; the low, mid and high class of soil available potassium was $<46 \mathrm{mg} / \mathrm{kg}$, 46-90 mg/kg and > $90 \mathrm{mg} / \mathrm{kg}$, respectively. The loam soil available potassium critical value was $51.4 \mathrm{mg} / \mathrm{kg}$; the function of sugarcane yield $(\mathrm{y})$ with soil available potassium $(\mathrm{x})$ was $\mathrm{Y}=12653.2+1154.3 \mathrm{X}-3.4 \mathrm{X}^{2}, \mathrm{r}=0.803^{* *}$; the low, mid and high of soil available potassium was $<52 \mathrm{mg} / \mathrm{kg}, 52-110 \mathrm{mg} / \mathrm{kg},>110 \mathrm{mg} / \mathrm{kg}$, respectively. The clay soil available potassium critical value was $60 \mathrm{mg} / \mathrm{kg}$; the function of sugarcane yield (y) with soil available potassium (x) was $\mathrm{y}=$ $57904.8-311.1 \mathrm{x}+5.5 \mathrm{X}^{2}, \mathrm{r}=0.853^{* *}$; the low, mid and high of soil available potassium was $<60 \mathrm{mg} / \mathrm{kg}, 60-120 \mathrm{mg} / \mathrm{kg}$ and $>120 \mathrm{mg} / \mathrm{kg}$, respectively.

(3) When potassium $\left(\mathrm{K}_{2} \mathrm{O}\right)$ application increased to $150-300 \mathrm{~kg} / \mathrm{ha}$, the sugarcane yield also increased. That benefit for sugarcane decreased when application of $\mathrm{K}_{2} \mathrm{O}$ was $450 \mathrm{~kg} / \mathrm{ha}$. Experiments of fertilization with potassium showed that the benefit decreased by degree. As for other minerals' effects, (K, Mg and S) on sugarcane yield, the application of $\mathrm{K}$ had the most marked effect, and the application of $\mathrm{Mg}$ and $\mathrm{S}$ also affected the yield. The treatments with potassium, magnesium and sulphur fertilizer increased sucrose content. Increasing the use of potassium, magnesium and sulphur fertilizer also increased sugarcane's fiber content.

ACKNOWLEDGEMENTS We would like to thank Mr. Liu Jiping for assisting with the field experiment. The author is also grateful to Dr. Portch of the Potash and Phosphate Institute of Canada for revising the manuscript and financially assisting this project. Financial support for this research was also provided by PPI/PPIC, The Natural Sciences Foundation of Guangxi (No.0448023) and The Natural Sciences Foundation of Guangxi Academy of Agricultural Sciences (No.2004003Z).

\section{REFERENCES}

Hunter, A. H. 1975. Laboratory and greenhouse technique for nutrient survey studies to determine the soil amendments required for optimum plant growth. International Soil Fertility Evaluation and Improvement. N.C. State University, May 20, 1975. Pp. 6-15

Xie, J, Zhou, J. and Hardter, R. 2000. “Potassium in Chinese agriculture”, Hohai University Press Pp. 201-225.

Zhang, Z. Tan, H. and Zhou, Q. 1998. "The soil potassium situation and the research of balanced fertilization in Guangxi”, China Agriculture Press Pp. 132-143.

Xie, J, Du, C. and Li, F. 1991. "Proceeding of the international symposium on the role of sulphur, magnesium and micronutrients in balanced plant nutrition" In: Soil magnesium status and prospects of magnesium requirements in south China. Pp. 262-272.

Morris, R. J. 1990. February 22, World status of sulphur and its agricultural uses. In: Proceeding from status and problem of sulphur in soil and fertilizer usages for economic crop production. Bangkok, Thailand. Pp. 35-39.

Received $25^{\text {th }}$ Aug. 2004

Accepted $7^{\text {th }}$ Feb. 2005 